\section{THE VIEWS OF THE YOUTH ON THE POTENTIAL FOR DIALOGUE BY MEANS OF DIGITAL MEDIA THROUGH PAULO FREIRE'S PERSPECTIVE}

\section{Cássia Ayres}

Lusófona University, CICANT (Portugal)

ORCID: 0000-0003-1080-1103

cassia.ayres2@gmail.com
LAS VISIONES DE LOS JÓVENES SOBRE EL POTENCIAL DE LOS MEDIOS DIGITALES PARA EL DIÁLOGO DESDE LA MIRADA DE PAULO FREIRE

\author{
Cicilia M. Krohling Peruzzo \\ University of State of Rio de Janeiro (Brazil) \\ ORCID: 0000-0002-6384-8848 \\ kperuzzo@uol.com.br
}

Para citar este artículo:

Ayres, C. \& Krohling Peruzzo, C.M. (2020). The Views of the Youth on the Potential for Dialogue by Means of Digital Media through Paulo Freire's Perspective. Commons. Revista de Comunicación y Ciudadanía Digital, 9(2), 104-132. http://doi.org/10.25267/ COMMONS.2020.v9.i2.03

Fecha de recepción: 15/04/2020. Fecha de aceptación: 16/05/2020

\begin{abstract}
This article seeks to analyse the perceptions of a group of young Brazilians digital media users, on the role of the Internet as a means to facilitating dialogue between them and their elected representatives in the political sphere, based on the presuppositions of Paulo Freire's pedagogy. The methodology focused on the use of qualitative approaches which involved in-depth, semi-structured interviews with thirteen young people from São Paulo and Bahia who participate in the online political participation program, $U$ Report. The findings suggest that the Internet is seen as having a limited role in dialogic processes by those interviewed, who also demonstrate that they are aware of the national situation and the structuring mechanisms of digital media.
\end{abstract}

\section{Resumen}

Este artículo pretende analizar las percepciones de un grupo de jóvenes brasileños usuarios de medios digitales sobre el papel de Internet como medio capaz de favorecer el diálogo entre ellos y los políticos elegidos en la esfera política, a partir de la pedagogía de Paulo Freire. La metodología seleccionada, de carácter cualitativo, se basa en entrevistas semiestructuradas en profundidad con 13 jóvenes en São Paulo y Bahía participantes del programa de participación política online U-Report. Los resultados sugieren que Internet tiene un papel limitado en los procesos dialógicos entre los entrevistados. Además, estos jóvenes demuestran ser conscientes de la situación del país y de los mecanismos estructurantes de los medios digitales.

\title{
Keywords
}

Youth, participation, digital media, Paulo Freire, Brazil

\section{Palabras clave}

Juventud, participación, medios digitales, Paulo Freire, Brasil 


\section{Introduction}

The participation of the youth in Brazilian political life is an issue without expressive visibility in the political arena and mainstream media. For the Brazilian anthropologist, Regina Novaes (2014), the preoccupation with young people relates to the future of society, since, ultimately, it will be the youth who will outline social changes based on their influence on other individuals and institutions. Therefore, it is necessary to consider that the political participation of the youth, understood as much in traditional politics as in civil society, does not take place in a cultural and historical void, "but in real societies that bear the unique marks of their history and the specific difficulties of their present" (Castro, 2008: 253).

The political participation of the current Brazilian youth has been enriched by the social mobilisations which relied on coordination through digital media together with the presence of millions in the streets. Digital communication channels have become a pathway for the exercise of individual and collective expression and opinion as well as the engagement of citizens in sociopolitical discussions in Brazil through mechanisms of digital participation (Barbosa \& Jeressati, 2017). In fact, it is apparent that the Internet has offered young Brazilians not only a set of relevant opportunities for social activism, whether in online or offline spaces such as: surveys, referendums, proposal of ideas, voting, public hearings, direct communication with politicians, and inspection of public spending, but also other forms of political participation already available in online media (Barbosa \& Jeressati, 2017).

One concrete example is the 2013 Jornadas de Junho demonstrations, also known as the 2013 June Journeys or Brazilian Spring. These demonstrations represented a historical milestone in the country's forms of political participation through social movements and had the fundamental importance of reshaping the political participation of these young people in Brazil (Gohn, 2018; Souto, 2016). For Gohn (2018), one of the great legacies of the 2013 June demonstrations was the influence of digital media, which engendered a type of political participation characterised by (de)institutionalization and an absence of formal leadership, but motivated by the different ideologies and causes with which the youth identify. 
However, Peruzzo (2013) considers that behind the digital media during the mobilisations that peaked in June, there was the Free Pass Movement, a movement for free public transport, and the Committees against the World Cup which took place years before the 2013 Jornadas de Junho demonstrations and were relevant in triggering the mobilisations articulated in the digital environment. In other words, although the Internet has played an important role in public debate and has encouraged the articulation of groups, which has culminated in the presence of thousands of Brazilians on the streets, simultaneously across several cities, the Brazilian mobilisations did not have their start in the digital environment (Peruzzo, 2013). It must be taken into account that Brazil already had a predisposition for struggle through historical social movements connected to the struggles for land rights, for the place of women in society, for education, the improvement of working conditions, respect for the environment, among many others.

Based on this last argument, the question this article asks is: what role has the Internet played in encouraging, especially among young Brazilians, the deliberation and influence of new decisions coming from public power? In this regard, Carrano (2012) warns that a good measure to gauge the quality of a process of youth participation is not whether or not young people can participate in the political space, but rather to seek to understand the extent of the reach of these individuals or collectives with their participation in order to influence decisions that affect their lives. In addition, Barbosa and Jeressati (2017: 1) define that "political participation refers to any activity aimed at influencing government action, either directly, by affecting the formulation or implementation of public policies, or indirectly, by influencing the choice of those responsible for such policies".

It is in these directions of political participation that this article is supported. Taking these into account, contrary to the potential digital media represents in the participatory dynamics of the Brazilian youth (Mizukami, Reia \& Varon, 2014; Souto, 2016), some studies conducted with young Brazilians showed that the Internet is a medium they consider limited and less effective when it comes to generating social change and when compared to more traditional forms of participation, such as street mobilisations and group action (Barbosa \& Jeressati, 2017; Souto, 2016). The Internet does not, therefore, seem to evoke an opportunity 
for dialogue between the youth and Brazilian politicians (Barbosa \& Jeressati, 2017). Particularly in the Brazilian context, it is still difficult to establish a direct link between the 2013 Jornadas de Junho demonstrations and the facts and events that followed those movements. The exploration of the empirical object of this study: the participatory dynamics of thirteen young Brazilians and what they consider to be the role of the Internet in facilitating social change, resonates with this idea of downplaying the digital medium as central to political participation. Taking into account the empirical findings that will be discussed further on, this article focuses on the contradiction between the large presence of the Internet in recent Brazilian political life, highlighted by the 2013 Jornadas de Junho demonstrations and the demonstrations for and against impeachment by President Dilma Rousseff in 2015 and 2016, and the existence of a communication gap between young Brazilian citizens and those who would be their representatives in politics, such as the President of the Republic, the Deputies, Governors, and Mayors, etc. It is known that communication between voters and elected representatives in the representative political system is tenuous or non-existent, if only exceptionally in local contexts or through digital social networks, which is not at all safe due to the unethical manipulation of its mechanisms, such as that which occurred in the 2018 elections in Brazil which favoured the victory of an extreme rightwing president. It is in this scenario that we seek to understand the perception of the young people interviewed on the role of the Internet in the post-election context of 2018, from the viewpoint of the Brazilian pedagogue, Paulo Freire (1987), regarding the relevance of dialogue in the construction of a transformative educational praxis which makes it possible to alter oppressive social contexts. Freire's notion of dialogue therefore constitutes an analytical lens through which to observe the dichotomies in the exercise of power in Brazil and the limitation of the role of the Internet, as well as the possibilities arising from a dialogical praxis capable of empowering the voices of young people and facilitating their recognition as individuals with rights.

This article begins by presenting the conceptual model, which is divided into three topics: (1) the context for the participation of young Brazilians, (2) the presence of the Internet among the most recent forms of political participation, and (3) the ideas of Paulo Freire and other authors on critical awareness, dialogue, empowerment, and popular education. The methodological processes are then 
described and justified. And finally, taking into consideration the methodology, this article presents some results from a broader ongoing research ${ }^{1}$ and discusses them in light of the Freirean perspective.

\section{Subject contextualisation}

\subsection{The plight of the most vulnerable of the brazilian youth}

From the perspective of the study with young people analysed by Abramo (2016: 113), the author infers that the youths admitted being "far from recognised as holders of rights and actively being included in the democratic process in Brazil". The author summarises that the social situation of the youth has deteriorated year after year in relation to essential rights such as education, health, public security, and work opportunities. In addition, the empirical work of Novaes (2014) published in the Observatório da Juventude (Youth Observatory) is even more specific as it refers to the three great fears of young Brazilians in contemporaneity, in particular, those at social risk: "the fear of being left behind" due to unemployment; "the fear of being disconnected", in a world connected and marked by new technologies, and "the fear of dying", prematurely and violently.

According to Cerqueira et al. (2018), in the document entitled Atlas of Violence (Atlas da Violência), the worsening living conditions of the vast majority of Brazil's youth, especially young black people, LGBT and men and women living in peripheral areas, makes them a target of violence in Brazil and places them at constant risk (Cerqueira et al., 2018). Another striking feature of the Atlas of Violence is that deaths are greatly associated with skin colour (Cerqueira et al., 2018). The black population's victimization rate increased $23,1 \%$, while in the non-black group, the rate decreased $6,8 \%$. In general numbers, the homicide rate for the black population was 40,2\%, while the same indicator for the rest of the population was $16 \%$. This implies that $71,5 \%$ of the people who are murdered each year in Brazil are of black or mixed race (Cerqueira et al., 2018). Therefore, it is important to pay attention to the situation of social inequality in which the most affected of the youth are those from the lower classes. This is why it is most

1. Conducted by Cássia Ayres for her PhD thesis in Communication for Development Studies. 
correct to speak of the youth, in the plural, because their realities are differentiated according to their economic conditions of class, housing, access to education, and ethnic condition, etc.

Another group at permanent risk of violence is that made up of Lesbian, Gay, Bisexual, and Transgender people (LGBT). A study conducted in 2019 by the Gay Group of Bahia (GGB) and published by the newspaper 0 Globo showed the number of 329 violent deaths during that year ${ }^{2}$. Clearly, the consequences of these risks generate in the youth permanent feelings of insecurity in the present and great uncertainties about a promising future (Ribeiro, Lânes \& Carrano, 2005).

The degradation of the social condition of the youth is also the subject of research for Maria da Glória Gohn in her recent work on forms of political participation of young Brazilians after June 2013. Gohn (2018: 117) argues that the latest statistical surveys show that the number of unemployed is much higher among young people. The crisis in the labour market affects them not only "from an economic point of view, but also in the political-cultural sphere". For Gohn (2018), the problems that arise from this; such as recession, corruption, and violence, erode the confidence and hope of young people for a better future, including the spaces for speaking and listening. Evidence of this can be found as recently as 2019, when the government of President Jair Bolsonaro was established, where spaces for participation and political deliberation were gradually constrained rather than expanded and valued (Leal, 2019). In April 2019, the presidential decree $9.759^{3}$ announced the elimination of hundreds of social councils with popular participation responsible for the debate and monitoring of public federal policies in different areas that require the attention of minority populations such as indigenous people, Afro-descendants, the homeless, and LGBT people. This measure prevents the direct engagement of civil society to influence affirmative public policies regarding these groups, considered to be the most vulnerable.

\footnotetext{
2. See: shorturl.at/FGIOT

3. Decree 9. 759 of April 11, 2019 risks the continuity of some 700 councils linked to direct and indirect public administration. Visit: https://rb.gy/c3lmba
} 
This tendency to restrict the spaces for participation of vulnerable groups and civil society in general, seems to align with the intentions of President Jair Bolsonaro on his ideas regarding the political participation of the Brazilian youth. In a speech made after the inauguration, the President alluded that the government would value boys and girls who begin not by being interested in politics, as it is currently in schools, but begin by learning things that can take them into (outer) space in the future ${ }^{4}$. This statement comes in a context in which the President was evaluating the learning outcomes of the youth in the International Student Assessment Program, PISA in which Brazil has dropped and lost positioning compared to other evaluated countries in the areas of biology, languages and reading, and mathematics ${ }^{5}$.

The Government project for investment in long-term education which could lead young people to space gained contradictory contours when the government made cuts in public funding for higher education. In March 2019, Bolsonaro's government announced a $\mathrm{R} \$ 5.8$ billion (US $\$ 1,14$ billion) reduction in funds for public universities and programs to promote research in Brazil and abroad. Furthermore, the president-elect has reduced public investment in full-time educational programs such as day-care centres, literacy, and also in high school and technical education ${ }^{6}$. The education cuts in the public budget essentially harm children and young people who depend on free education, such as low-income populations, especially those of African descent and indigenous quota holders (beneficiaries of a quota system) who enter public universities as a result of good performance in the National High School Exam (ENEM) ${ }^{7}$.

\subsection{The youth, political participation, and the Internet}

Better educated, less religious (especially less Catholic), more urban, and selfdeclared less white and privileged, with an elevated consumption of new technologies, especially the Internet and the use of mobile devices, these young

4. See: Estadão. Available at https://rb.gy/6lqt8t

5. Brazil had a fall in the areas evaluated. The country ranked 63rd in science, 59th in reading, and 66th in mathematics. Visit https://rb.gy/qt90x0

6. See: https://rb.gy/vxn4mb

7. See: https://rb.gy/tresnh 
people, born after the Diretas Já ${ }^{8}$ campaign, were raised in the context of the re-democratisation of Brazil after the military regime (1964-1988). These new participants in national political life are further removed from institutionalised state structures. They have grown up without the same passion for political parties as their parents and, in general, are averse to traditional ways of doing politics (with parties and trade unions), and as a result, their civic and political actions tend to be more non-partisan (Souto, 2016; Gohn, 2018).

On the 2013 Jornadas de Junho demonstrations, Souto (2016) and Gohn (2018) allude that these represented a singular moment in the conjuncture of Brazilian political participation. More specifically, Souto (2016: 265) states that "it is impossible to talk about the youth and political participation without referring to it". The author adds that June 2013 was a milestone which seems to have cooled the arguments of those who, "while looking at the youth through distorted lenses, proclaimed their apathy and their disinterest in politics". Thus, the popular demonstrations that began in June 2013, for example, proved that the Internet was able to mobilise thousands of people around causes that aroused their dissatisfaction (Gohn, 2018; Souto, 2016). These demonstrations have shown their political character "in the broad sense, as they express themselves in the form of protests and demands for change in critical areas of national life and for public social interest policies" (Peruzzo, 2013: 78). In the view of this Brazilian author, the 2013 Jornadas de Junho demonstrations transcended the dimension of class and party-political and ideological orientations. There was a heterogeneous character, predominantly young people, dissatisfied with the Brazilian social, economic, and political situation, who without understanding why wanted to change Brazil (Peruzzo, 2013).

It was these youths, initially mobilised by the Free Pass Movement ${ }^{9}$, who helped to call for mobilisation throughout the country, but who extrapolated it, who demonstrated their dissatisfaction, and sought visibility using smartphones and posters; and who expressed their opinions on social networks and alternative means, whose content eventually transcended the mass media. Therefore, the use of digital technologies represented a fundamental differential that mobilised the country with large public demonstrations (Peruzzo, 2013: 79), which surprised

8. Large public demonstrations demanding direct elections for the presidency and other representative positions in 1984, at the end of the military dictatorship.

9. Movement that defends a zero tariff in public transport. 
the Executive and the Parliament for its breadth and instantaneity, ending in repression by the police apparatus with a disproportionate display of violence against demonstrators (Gohn, 2018; Peruzzo, 2013).

However, remnants of the Jornadas de Junho in subsequent months appear in other forms of civil articulation that later gain prominence in liberal and conservative organizations with a strong partisan tendency, such as the Movimento Brasil Livre and Vem Prá Rua. These, among others, aligned themselves with the conservative agendas in favour of the impeachment of the then president Dilma Rousseff who was democratically re-elected in 2014. These movements were active in 2015 and 2016 and championed causes defended by conservative and liberal political parties, businessmen, and dissidents, etc., as well as Jair Bolsonaro's election campaign in $2018^{10}$. In opposition to these forces, there was also a strong movement against the impeachment led by large fronts ${ }^{11}$ made up of social movements, trade unions, and other progressive associative forms, but which did not succeed in stopping the impeachment that took effect on August 31, 2006.

Returning to the issue of the Internet, although the Internet did not foster the social mobilisations that were part of the June 2013 demonstrations, which are the result of a process of historical awareness of Brazilian society that dates back decades of progressive social struggle (Peruzzo, 2013), the digital medium, according to Gohn (2018), created new forms of sociability in civil society, in which some of these young people are now organized horizontally, acting in collectives or in new social movements that emerged after the June 2013 demonstrations.

On the issue of youth participation as Gohn (2018) points out, the popular demonstrations that took place in Brazil from 2013 onwards showed that in reality the authorities, public administrators, and civil institutional representatives had (and still have) difficulty interacting with young people because they have not followed the changes in the youth's daily practices, considering the new forms of sociability and communication generated on digital social networks. However, despite this pertinent observation, the Internet cannot be considered an epicentre

10. Leaders and other members of these groups eventually joined liberal and conservative political parties and participated as candidates for elected office, with some being elected.

11. Frente Brasil Popular (Brazil Popular Front) and Frente Brasil Sem Medo (Fearless Brazil Front). 
of civil participation, since access to it is not universal to all the youth in Brazil ${ }^{12}$. It is important to recognise that the traditional forms of communication and participation persist from the geographic territories in which they live.

Another interesting point of view on the limitation of the Internet as a form of participation among Brazilians again comes from the data of the 2016 study, Agenda Juventude Brasil. In this study, Souto (2016: 279) draws attention to the fact that young people identify acting via the Internet as "a relatively less effective form of political action" when compared with the alternatives evaluated by the author in the study (street mobilisations and direct actions, acting in associations or collectives, acting in councils, conferences, public hearings). According to the conclusions of this study, young people confirm that the act of expressing an opinion on important issues or charging politicians through online channels "is weak in that it refers to a mere individual action" (Souto, 2016: 279). Converging with this opinion, Mesquita and Cantoni (2016) consider that however much the Internet has (and has had) great potential to contribute to the improvement of participation in spaces considered more traditional (such as party affiliation and voting), it does not give young people a sense of being effective in creating dialogue with their representatives.

Furthermore, linking the effectiveness of the Internet to the political will to allow citizens a voice, Edwards et al. (2018: 15) warn that the perception that the Internet facilitates participatory dialogic processes can be relative and even "illusory". The position of these authors is based on the fact that in many developing countries, including Brazil where the Making All Voices Count project operates, the proliferation of virtual spaces is occurring in a scenario of narrowing and systematic closure of presential spaces for political action and civil society organization in a process led by the power of states (Edwards et al., 2018). This phenomenon would be related to the so-called "fear factor" (Edwards et al., 2018: 15) whereby the State fears confronting the demands of civil society, which is motivated by a generalized distrust of society in its political representatives and their capacity to act in favour of its demands.

12. See: TIC Kids Online Brasil (2018). Available at https://rb.gy/nfh0f5 


\section{Conceptual framework}

\subsection{Dialogue and critical awareness in the Freirean vision}

In the work Pedagogy of the Oppressed, Paulo Freire (1987) introduces the presuppositions of the "Pedagogy for Liberation". This pedagogy is by nature popular and communitarian which has a fundamental category of awareness, seen as necessary to transform the unequal reality to which large contingents of the population, at the time called the masses, are subjected. He was concerned with people not reached by the traditional education system and thus developed a method of adult education, applied in rural areas of Brazil and other countries. This pedagogy is based on dialogue, reflection, and critical awareness as essential bases for what Freire (1987: 44) calls "liberation" from the dominating mindset, or to cease thinking with the heads of others.

For Freire:

Dialogue is the encounter in which reflection and action, inseparable from those who are in dialogue, are directed toward the world which needs to be transformed and humanised, this dialogue cannot be reduced to depositing ideas into others. It cannot become a simple exchange of ideas, ideas to be consumed by the transformers. Nor is it a hostile discussion between men who are not committed either to calling the world by its name or to the search for the truth, but to the imposition of their own truth. (1979: 83)

The process of liberation implies, in horizontal relations between the learned and the learners, that the knowledge of the other is recognised and together they generate knowledge. On the contrary, the vertical relationship of A with B is anti-dialogue. "In anti-dialogue, that relationship of 'sympathy' between its poles that characterises dialogue is broken. Therefore, the anti-dialogue does not communicate. It makes communications" (Freire, 1981: 92).

This verticality gives rise to "banking education", or part of a system that involves the teacher as the holder of the knowledge who then transfers it to the students, without considering the critical capacity of the students, which results in their gradual dehumanisation (Freire, 1987: 46). 
Dialogue being an inherent part of a critical awareness education process, Freire (1987) considers that students, not just teachers, should raise the problems they experience and discuss them from a critical perspective. Therefore, it is through a dialogic process between teachers and students that reflection is engendered and critical awareness reached to form the educational praxis that Freire calls a "humanist and liberating praxis" in which the latter become subjects, and are able to fight for their emancipation. Thus, for Freire (1987), the school is an arena for the exercise of political rights and, therefore, education and politics are inseparable. As Gadotti (2008) says, to educate is to act politically. Therefore, it is about education for citizenship, and bringing it to the field of Communication, Peruzzo (1999: 224) reminds us that the idea that "communication is a pedagogical act and education is a communicative act", to show the inseparability also between communication and education.

This same interrelation can be thought of in informal and non-formal education, and not only in formal education, whose process is called popular and community education (Peruzzo, 1999). This is one of the educational paradigms inspired by Freire that has as its foundation awareness aimed at social transformation. According to Gadotti (2000: 6), "popular education practices also constitute mechanisms of democratisation in which the values of solidarity and reciprocity and new alternative forms of production and consumption are reflected, especially the practices of popular education, often voluntary", in the third sector.

Considering the intersections between formal education and other educational institutions in the lives of the subjects, it is worth noting that the young people interviewed also benefit from non-formal and informal education by participating in U-Report, a programme linked to UNICEF that aims to engage with young people from all over the world to get involved and talk about issues that are important to them ${ }^{13}$. 


\subsection{Transformational pedagogy and empowerment}

In the Freirean vision, dialogue is the existential need of human beings to change their realities, which is what the Brazilian pedagogue calls transformative pedagogy (Freire \& Macedo, 1987). Transformative pedagogy is, therefore, an educational approach that promotes personal experience and encourages the autonomous action of individuals. Freire and Macedo (1987: xi) argue that this educational approach enables students to have not only an ability to read the word, but also the "palavramundo" (word-world), which means "to read the world, reading the word". Through this notion of "reading", the human word is more than mere vocabulary, it is action. Through transformative pedagogy, therefore, the cognitive dimensions of the literacy process must include the relationships of men with their world.

The notion of reading the "palavramundo" (word-world) developed by Freire and Macedo (1987: xi) was recently appropriated in the fields of educommunication (Soares, 2000) and critical media literacy (Brites et al., 2018; Kellner \& Share, 2007; Livingstone, 2011; Yoon, 2016) as a premise that the mass media is not neutral, but operates under systems of power, ideology, and hegemony and often serves to "give a voice to or silence certain groups and individuals" (Yoon, 2016: 8).

From this Freirean perspective, empowerment stems from the creation of a critical awareness, and not from pure and simple action, which the author calls "activism", or action without reflection (Freire, 1987: 45). Critical awareness and empowerment, like the ability to give direction to processes, unlike "activism", arises when people develop the power to critically perceive what their role is in the context in which they find themselves from an examination not only of their reactions and behaviours, but above all from relationships with others and from these in broader current and historical contexts. It is, therefore, by questioning continuing patterns of oppression and abuse of power, that individuals become active subjects and discover their potential to strengthen themselves together and acquire a sense of agency (Freire, 1987). Thus, the process of the perception of being a subject for Paulo Freire means being an autonomous person with the power to guide one's own life, by participating in a social and political realm. Therefore, for Freire, not being a subject means being "castrated of one's power to create and recreate, of 
one's power to transform the world" (Freire, 1987: 19). As part of an ongoing process, empowerment is a process that involves conflict in order to gain power through critical awareness and is made possible by the collaborative social action of citizens. According to Gohn (2004), this conception of empowerment in the Freirean vision of dialogue is inseparable from political thought and constituted the basis of the emancipation movements in Brazil from the 1990s even before the post-dictatorship Brazilian re-democratisation of 1964.

\section{Methodology}

The methodological choice of this study focused, fundamentally, on the use of qualitative approaches supported by semi-structured, in-depth, face-to-face interviews with thirteen young Brazilians ( $\mathrm{F}=7 ; \mathrm{M}=6$; between 16 and 22 years of age) from the states of São Paulo and Bahia in Brazil, between May and June of 2018 in the pre-election period. After the elections, online interviews were conducted using the WhatsApp platform in July 2019 with six of the original thirteen invited in order to complement the initial face-to-face interviews. In this second round of reduced interviews, the aim was to find out what these youths thought of the role of digital media during the presidential elections and how they self-evaluated their political participation in online media a year later.

It is important to emphasise how the participants were found and what methods were used in the selection process. Those selected participate in a communication for development program, U-Report, which aims to ascertain the opinions of young Brazilians on issues related to their daily lives, mainly: health, sexuality, politics, and education. The thirteen young people interviewed volunteered for the research by way of an invitation extended to U-Report's platform database via Facebook, SMS messages, and Twitter. The thirteen selected participants are users of this online platform and made themselves available for in-person interviews.

The use of in-depth interviews is justified in that it better suits the purposes of exploring and understanding the discourses, behaviours, and subjective positions of the individuals' daily lives (Denzin, 2009), in this case the participatory dynamics of young people in pre and post-election moments in Brazil. 
The thematic analysis process was based on the discourse analysis technique (Fairclough, 1992, 1997) in which an initial codification of the fragments of the participants' discourses into smaller semantic units was carried out and refined. Throughout the refinement of the codification, the participants' similar and opposing ideas were connected to discover patterns in the data. These were observed within the analytical framework (Fereday \& Muir-Cochrane, 2006), to facilitate understanding awareness from the Freirean vision of dialogue in relation to three themes for analysis: the context in which the youth participate, what they perceive as social changes that motivate them to participate, and the role of the Internet in this participatory process.

Finally, it is important to note that following an ethical protocol was extremely relevant in working with young people (some of whom are in vulnerable situations due to their African descent, their living in peripheral areas, and their being LGBT). Written consent was obtained and their privacy respected, therefore, their anonymity has been maintained during the interviews and they were given fictitious names for the purpose of this article.

\section{Findings and discussion}

In general, the participants expressed very similar opinions with regard to the challenges of dialogue with their peers and of being heard by representatives in national politics using online media. Similarly, the participants all downplayed the role of digital networks in informing and enabling political participation for the social changes they wish to see. Some of the main causes that lead them to downplay the Internet among presential forms of political and civic participation (such as social groups, the student union, and volunteering) are the climate of hostility (hate speech), fake news, and the presence of algorithms which segment them into digital bubbles. Additionally, for these young people, the current context of political-party polarisation, which characterised the 2018 elections $^{14}$, and the changes promoted by the president-elect since taking office on 1st of January 2019,

14. Extreme right-wing groups, supporters of the current President Jair Bolsonaro and left-wing groups, supporters of progressive trends. 
which have disfavoured young people, especially the most vulnerable among them, are the main inhibiting factors in facilitating dialogue in the online environment and hinder bringing young people and their representatives together.

When considering the context in which the majority of young Brazilians are inserted, it is important to note that the thirteen youths who collaborated with this study represent a small minority, distinct from the overall youth population. These are young people who live in large urban centres, who have extensive access to information, including the Internet, and who integrate spaces for reflection and critical discussion with their peers, mostly in person. Moreover, more than half of them participate actively in their communities as volunteers and have demonstrated a high level of awareness of their realities, including their role as citizens and knowledge of media mechanisms, as the following results demonstrate. One of the possible reasons for this is that they are engaged in U-Report, a platform that advocates contributing to the fostering of critical thinking, informal education and the encouragement of civic participation ${ }^{15}$.

\subsection{A new scenario for youth participation}

The participants were asked what had changed in the scenario of political participation in Brazil since the 2018 elections. The responses converged on an environment not conducive debate and dialogue. For them, the political-ideological polarisation has generated an environment of intolerance, hostility, and fear of expressing themselves not only in the online environment, but also face-to-face, where it is difficult for people to understand each other.

The differences in opinion already noted by these young people have, since the campaign period, only increased after the results and the first seven months of the elected president's administration. The contrasts served to separate childhood friends, close family members, and in many cases, became a warning of social conduct where it is more prudent to adopt neutrality than to align with the political parties or causes with which these young people identify. Especially

15. See: http://ureportbrasil.org.br 
on the Internet, young people are choosing to quell their attempts to resist the conservative thinking they associate with the government elected in October 2018.

It is important to mention that in an absolutely unintentional way (since it has already been made explicit the random nature of the constitution of this group), the thirteen young people interviewed have a political-ideological position contrary to that of the elected government. In their statements, these young people are clearly discontent with the political measures which involve the loss of rights they consider to be essential ${ }^{16}$. Still astonished and afraid of the escalation of hostility by political-ideological polarisation since the election campaign period, these young people understand the weight of an environment of vigilance and disrespect for opinions contrary to their own as a progressive reduction of voice, of spaces for dialogue, and, consequently, of forms of empowerment.

For almost all the young people interviewed, the message is clear: "they don't want to hear us!", as Silvia ${ }^{17}$ said. Or from Vívian's perspective: "These politicians don't care about us". In a more cautious tone, Daniel sums up the context: "I'm LGBT, and black, I'm in a high-risk group, I have to take care of myself, because a good activist is a living activist!". On the subject, Silvia, a social services student in Salvador, adds to her initial talk in 2018 on the difficulty of being heard and the curtailment of dialogue when she is interviewed again a year later:

As a young woman, I feel violated, I see no prospect for the career I wish to pursue. The current government is messing with public policies and social issues. I see doors closing, danger of being an activist and of talking in the places where you are present, even on social networks because I might suffer an attack by some specific group that does not agree with my opinion. (Silvia)

João, a journalism student from São Paulo, emphasises the fear and constraint regarding the spaces for participation after the first seven months of government:

16. During the interviews the young people cited losses in education, in tolerance to gender equality, in the area of public security, and in employment opportunities.

17. The names are fictitious so as not to expose those interviewed. 
Ah! I'm afraid, huh? I think that this fear arises in several stages, I think that there are a series of achievements and political rights being revoked every day concerning the spaces of participation and the various points that people understood to be a victory for the young people who are being decimated. (João)

The two statements above converge with those of the other four participants interviewed in the second round in July 2019, with the difference that some of these young people, in considering themselves to be in a socially comfortable situation since they are neither black nor LGBT, do not truly feel the risk of the loss of rights and the curtailment of space and voice for themselves. Nevertheless, they acknowledge such phenomena in society in general and they feel for their peers. This is the case of Rui who, in answering the same question about what has changed in the forms of political participation, stated: "I'm actually in a very comfortable position with this government, because I'm a white, straight, middleclass man. Many of the people within my circle are those stigmatised by the government, people from the periphery and the poor".

When this context is seen from a Freirean perspective, the dialogue restrictions that the young people interviewed have faced in Brazil reflect the structural inequality of power between these young people and their representatives. According to Freire (1987: 137), "dialogue is an inherent part of the revolutionary and liberation process". Therefore, for the Brazilian pedagogue, the praxis of the people with revolutionary leaders presupposes that "citizens and their leaders must learn as much about dialogue as the use of power". Furthermore, for Freire, the revolutionary process as a dialogic cultural action requires a serious and profound effort of awareness through which citizens, by way of an educational praxis, "leave behind the status of objects to assume the status of historical subjects" (1987: 137). From this perspective, the conquest of essential rights by young Brazilians comes from the seizure of power, but the empowerment of the youth is more effective by actively participating in popular and community education that fosters awareness. According to Freire (1987), citizens and their leaders must maintain a critical engagement based on horizontal dialogue, so that citizens can defend themselves against trends that lead them into new forms of 
oppression from those holding power. It follows that the level of awareness of those interviewed is directly related to their involvement in the aforementioned platform U-Report.

\subsection{Social change and Freirean praxis in the participatory dynamics of the youth}

For the young people interviewed, the act of political participation is intrinsically linked to the social changes they seek to experience in Brazil. When asked what social change means to them, these young people expressed a desire for a dignified life that begins with the right to be respected for their choices, to feel represented, and to enjoy basic rights such as quality healthcare and education, public safety, and work.

In the opinion of these young people, the steps toward social change begin with interpersonal relationships and with actions that can be facilitated by access to information, critical reflection, dialogue, and the sharing of points of view among their peers, family members, students, neighbours, and even among strangers. Within this systemic approach, many of the discourses have converged on the idea that everything begins with a change in mentality and individual behaviour, that is, awareness, knowing how to read the world, which subsequently reaches the collective, and then moves into the wider fields of politics and economics. Three young people from São Paulo interviewed in May 2018, summarise these findings well: "That word is about society evolving with differences. Changing minds, to accept the differences in others. Differences of opinion, skin colour, finances, culture" (Joana):

Social change is when a group of people creates a new debate and brings other groups of people together. This ends up generating an awareness, it ends up generating a change of opinion and a change of behaviour that spreads to the whole of society. (Gina)

Social change, for me, is not only about being together and talking about social or financial issues, but also about how I see you and how you see me. And I think that by changing behaviour, you end up changing the whole, politics and economics. (Inácia) 
In general, young people also realise that they have a preponderant and transformative role as social actors but are not seen as such by politicians. Another relevant aspect identified in this study is that these young people consider education to be a pillar for social change. It underpins equal opportunities to benefit from rights and it influences the fight against racism and prejudice that some have revealed feeling ${ }^{18}$. In fact, the feeling of social injustice is what drives them to act informally as quasi educators in their social networks. At least ten of the thirteen young people consider themselves to be influencers of their peers and family members for a new mentality, more attentive to their realities through reflection on the issues that afflict them.

João, a recently graduated journalist from São Paulo is a good example of this set of findings. He says he uses social networks and personal encounters to raise awareness among his peers "with quality information and humorous memes on the topic of recognition, so that they feel empowered". When asked what most afflicts him in his reality and what motivates him to participate, he responds:

I would like to be seen and accepted in all spaces, for people like me feel accepted, seen, and to feel positive. I think that social change would be to arrive at a job interview and not be asked if I am a drug addict. I wouldn't want my friends to go through that. (João)

The perception of social change as intrinsically linked to education and changes in behaviour and collective mentality refers to the theoretical framework of Freirean pedagogy that presupposes personal and peer awareness in the collective as part of the political act to unveil reality and participate in the decisions that concern them (Freire, 1981, 1987). In line with this thinking, the participants realise that education is a factor that reduces prejudice and the social stigma that afflicts them. The action of João and the other young people interviewed, who consider themselves influential in the awakening of critical awareness in themselves and in their peers, refers to Freirean pedagogical praxis for the transformation of individuals into subjects aware of their realities and capable of acting on oppressive structures. According to the Freirean perspective, subjects do not liberate themselves alone, they liberate each other, through dialogic processes, through reflection and problem solving, and thus empowering each other (Freire,

18. It is important to point out that at least five of the thirteen young people come from social backgrounds with low purchasing power and self-identify as black, periphery (living far from urban centres), LGBT, and had parents who did not reach or even complete high school. 
1987). The participative dynamic of these young people (whether online or offline) is in keeping with not only the place of critical awareness in the liberation from oppressive structures, but also as the principle of collective awareness.

\subsection{More Internet and less dialogue: the critical literacy space}

When considering the context of polarisation and precariousness of dialogue already mentioned, these young people are relying on spaces that they consider to be the safest in order to make themselves heard and included. On the one hand, the Internet offers them some protection to express their opinions, it offers "the cloak of invisibility to young people" as Vívian describes, but on the other hand, it seems that "nobody wants to listen to anybody" on social networks, as Rui said. On this topic, the participants were asked about the role of digital media in two ways, the first related to the function of informing and engaging citizens for social change, and the second related to the effective social changes they wish to experience. The results show the young people interviewed tend to occupy spaces where they feel the safest, giving the examples of in-person networks, conversations between friends, the school environment, and in cultural groups as preferred forms of participation for them. Being among those they know and with some freedom to express themselves means putting themselves at less risk for these young people and sometimes the Internet collaborates, but in other cases, which have already been mentioned, it does not. In short, the Internet is seen by these young people as a resource for political participation that empowers and equips them for action through access to the information they need and which allows them "a possibility to protest", as Joana said, but is far from changing the social realities they want to experience.

Concerning this dichotomy, Fernando thinks that although the role is positive in its ability to engage and inform, he has difficulty turning the content of the Internet into concrete results and advances: "It is useful to inform, but what is this information good for? Is it just to outrage people? Or is it to do something?" 
Without referring to Freire, this position is in line with one of the presuppositions made as he talks about the necessary relationship between awareness and action for transformation through self-organization. Fernando complements his point of view by saying that "it is a question of people also using the Internet in a productive way, because then it will play an important role". In the same vein, Daniel argues: "on the Internet, you don't have the same complexity of the debate you usually have in person. I don't think it yields as much as face-to-face meetings do, you know?".

Overall, all thirteen interviewees, in some way, criticized the role of the Internet as a participatory mechanism capable of engendering social change. The main reasons for the discontent and ambivalence of this role include fakes news, filter bubbles, and hostility practices or trolling. Distrust of the veracity of the news, lack of visibility, and fear of expressing political opinions in an environment they consider intolerant (especially after the 2018 elections) influence both the vision and the participatory practices of these equally ambivalent young people in their physical and virtual social lives.

For Rui, for example, "the inundation of fake news during the election period was very shocking" and this encouraged him to learn more about the fake news apparatus and how to better defend himself, the same occurred with Filomena, Fernando, and João. For another group of young people, however, the strategy was to distance themselves due to disbelief in the power of this medium to inform and engage, as was the case with Silvia, Larissa, Gina, and Daniel. This last participant summarises the position of this group:

I think the situation of the electoral debate in Brazil was polarised to a level where there was very little openness to dialogue, to discuss with people. Whoever was going to vote for Bolsonaro was going to, and whoever wasn't, wasn't going to. I didn't get involved! (Daniel)

The mechanism of digital bubbles determined by the algorithms of big companies like Google, Facebook, etc., also restricts the possibility of a diverse and inclusive dialogue. With a high awareness, both Paulo and Filomena summarise their views on the algorithm that segments users on the networks: "It is alienating to live inside the bubble. In the end, you only talk to those who share the same ideas. We need 
to pierce the bubble" (Paulo). "Many young people don't know, but what you follow keeps appearing, whoever doesn't know, or click 'like', it won't reach them" (Filomena).

When these criticisms are analysed in line with the transformative pedagogy on critical awareness which comes from reading the word-world (Freire \& Macedo, 1987), it is observed that the young people interviewed had the opportunity to learn about critical-media literacy, which stimulates critical awareness so that they are more attentive to media content that reflects or distorts their realities (Kellner \& Share, 2007; Livingstone, 2011; Yoon, 2016). Through this critical reading of the word and the world, individuals would be better able to create their own meanings and identities in order to emerge from the condition of subordinate and invisible audiences (Freire \& Macedo, 1987) and be able to shape and transform the material and social conditions of the society in which they live (Kellner \& Share, 2007). In particular, with regard to the analysis of the Brazilian context, in which they operate, critical literacy or educommunication may have contributed to young people developing skills related to perception, critical analysis, personal content creation, sharing of information, and increasing participation whether it be online, offline, or a combination of the two as this analysis demonstrated.

\section{Conclusion}

On the whole, the participants reveal that they have a critical view of the reality of the Brazilian youth, especially in the peripheries of large cities. They claim equal treatment and work opportunities, as well as respect for differences. They realise the limitations of the communication environments provided by the Internet, they are outraged by the exclusionary political-ideological oppositions of the other, but at the same time, they consider it necessary to use them in a favourable way for social struggles for rights and democratic participation. However, they believe that presential communicative relationships are more conducive to transformative dialogic communication. 
In view of this framework, it should be noted that in the most recent history of Brazilian political participation, the Internet, per se, has not fostered young peoples' dialogue with their peers or with their representatives in the political sphere in a way that enables them to intervene in the decisions that affect them. In other words, they do not believe it is possible to be more widely heard or intervene in contrary decisions and visions through social justice by means of the Internet.

Despite the downplay of the role of the Internet in participation in social change, together with an adverse political context to the social conquests of young people, and imposing restrictions on the one hand, it seems, on the other hand, to motivate this group to act as influencers of a new mentality that is pro-representative of young people in their micro contexts. It is in this context that Freire's awareness raising perspective becomes timely to understand the importance of the awareness process and of dialogue so that people can think and see the world in a critical light from their experiences and the desirable emancipatory relationships in the exchange of knowledge with their peers at all levels of education. 


\section{Bibliography}

- ABRAMO, H. W. (2016). Identidades juvenis: estudo, trabalho e conjugalidade em trajetórias reversíveis. In D. PINHEIRO, E. RIBEIRO, G. VENTURI \& R. NOVAES (Orgs.), Agenda Juventude Brasil: leituras sobre uma década de mudanças (pp. 19-61). Rio de Janeiro: UniRío. Retrieved from https://rb.gy/feor6g

- BARbosA, A. \& JERESSATI, T. (2017). Panorama setorial da Internet. Participação cidadã na era digital: e-Participação, 9 (3), 1-16. Retrieved from https://bit.ly/3eEqPUH

- BRITES, M. J., AMARAL, I. \& CATARINO, F. (2018). A era das "fake news": o digital storytelling como promotor do pensamento crítico. Journal of Digital Media \& Interaction, 1(1), 85-98. Retrieved from https://bit.ly/2COEc7q

- CARRANO, P. (2012). A participação social e política de jovens no Brasil: considerações sobre estudos recentes. O social em questão, XV (27), 83-99. Retrieved from https://bit.ly/2Ce8tgp

- CASTRO, L. R. (2008). Participação política e juventude: do mal-estar à responsabilização frente ao destino comum. Revista Sociologia Política, 16 (30), 253-268. Retrieved from https://www.scielo.br/pdf/rsocp/v16n30/15.pdf

- CERQUEIRA, D. C. et al. (Org.). (2018). Atlas da violência. Retrieved from https:// cutt.ly/TuPr9Ty

- DENZIN, N. K. (2009). The research act: a theoretical introduction to sociological methods. New Jersey: Aldine Transaction. Retrieved from https://bit. ly/2B9NgDz

- EDWARDS, D., HUDSON, H., ANDERSON, C., MCGEE, R. \& BROCK, K. (2018). Supporting innovation and the use of technologies in accountability initiatives: lessons from Making All Voices Count. Retrieved from https://bit.ly/30k5VVY 
- FAIRCLOUGH, N. (1997). Discurso, mudança e hegemonia. In E. RIBEIRO (Org.), Análise Crítica do Discurso: uma perspectiva sociopolítica e funcional (pp. 6785). Lisboa: Editorial Caminho.

- FEREDAY, J. \& MUIR-COCHRANE, E. (2006). Demonstrating rigor using thematic analysis: a hybrid approach of inductive and deductive coding and theme development. International Journal of Qualitative Methods, 5 (2), 80-92. Retrieved from shorturl.at/wzBL5

- FREIRE, P. (1979). Conscientização: teoria e prática da libertação: uma introdução ao pensamento de Paulo Freire. São Paulo: Cortez \& Moraes. Retrieved from https://bit.ly/395hGn7

- FREIRE, P. (1981). Educação como Prática de Liberdade (12ª edition). Rio de Janeiro: Paz e Terra.

- FREIRE, P. (1987). Pedagogia do Oprimido. Rio de Janeiro: Paz e Terra.

- FREIRE, P. \& MACEDO, D. (1987). Alfabetização: Leitura do mundo, leitura da palavra. Rio de Janeiro: Paz e Terra.

- GADOTTI, M. (2000). Perspectivas atuais da educação. São Paulo em Perspectiva, 14 (2), 3-11. Retrieved from https://www.scielo.br/pdf/spp/v14n2/9782.pdf

- GADOTTI, M. (2008). Escola cidadã. São Paulo: Cortez \& Moraes.

- GOHN, M. D. G. (2004). Empoderamento e participação da comunidade em políticas sociais. Saúde e sociedade, 13(2), 20-31. Retrieved from https:// rb.gy/nd0qvp

- GOHN, M. D. G. (2018). Jovens na Política na Atualidade: uma nova cultura de participação. Caderno $C R H, 31(82), 117-133$. Retrieved from https://rb.gy/ u3stfh

- HERRINGSHAW, V. (2018). Increasing citizen voice and government responsiveness: what does success really look like, and who decides? Retrieved from https://bit.ly/2CGZWCv 
- KELLNER, D. \& SHARE, J. (2007). Critical media literacy, democracy, and the reconstruction of education. In D. MACEDO \& S.R. STEINGERG (Eds.), Media literacy: A reader (pp. 3-23). New York: Peter Lang.

- LEAL, L. (2019, 19, April). Constranger a democracia: a participação sob ameaça no Brasil. Público. Retrieved from https://rb.gy/ikz7dc

- LIVINGSTONE, S. (2011). Internet Literacy: Young People's Negotiation of New Online Opportunities. MATRIZes, 4 (2), 11-42. doi: 10.11606/issn.1982-8160. v4i2p11-42

- MESQUITA, N.C. \& CANTONI, S. (2016). Participação política On-line vs. off-line no Brasil. In N.C. MESQUITA (Org.), Brasil: 25 anos de democracia: participação, sociedade civil e cultura política (pp. 123-143). Rio de Janeiro, Fundação Konrad Adenauer. Retrieved from http://bibliotecadigital.tse.jus.br/xmlui/handle/ bdtse $/ 4930$

- MIZUKAMI, P. N., REIA, J. \& FERRAZ, J. V. (2014). Mapeamento da mídia digital no Brasil: Um relatório da Open Society Foundations. Retrieved from https:// rb.gy/yslka7

- MOREIRA, A. (2019, May). Jovens no Brasil de Bolsonaro: Está difícil sonhar em um país deste jeito. Brasil de Fato. Retrieved from https://rb.gy/vxn4mb

- NOVAES, R. (2014). Mal-estar, medo e mortes entre jovens das periferias e favelas. Retrieved from https://rb.gy/ekoob4

- PERUZZO, C. M. K. (1999). Comunicação comunitária e educação para a cidadania. Comunicação \& Informação, 2 (2), 205-228. doi: 10.5216/c\&i. v2i2.22855

- PERUZZO, C. M. K. (2013). Movimentos sociais, redes virtuais e mídia alternativa no junho em que "o gigante acordou"(?). MATRIZes, 7(2), 73-93. Retrieved from https://rb.gy/bxbvh1 
- RIBEIRO, E., LÂNES, P. \& CARRANO, P. (2005). Juventude Brasileira e democracia: participação, esferas e políticas públicas. Retrieved from https://bit.ly/3h7VQCa

- SOARES, I. O. (2000). Educomunicação: um campo de mediações. Comunicação \& Educação, 19, 12-24. doi: https://doi.org/10.11606/issn.2316-9125. v0i19p12-24

- SOUTO, A. L. S. (2016). Juventude e participação. In D. PINHEIRO, E. RIBEIRO, G. VENTURI \& R. NOVAES (Orgs.), Agenda Juventude Brasil: leituras sobre uma década de mudanças (pp. 265-286). Rio de Janeiro: Unirio. Retrieved from https://rb.gy/feor6g

- YOON, B. (2016). Critical literacies: Global and multicultural perspectives. New York: Springer. 


\section{Biographies}

\section{Cássia Ayres}

Lusófona University, CICANT (Portugal)

ORCID: 0000-0003-1080-1103

cassia.ayres2@gmail.com

PhD candidate in Communication for Development Studies at Lusófona University (Portugal). She holds a MSC in Corporate Social Responsibility \& Sustainability from Aston University (England) and Advanced Studies in Communication for Development from Malmö University (Sweden). She has been working with communication and sustainable development for more than 18 years for public, private and non-profit sectors. Currently, she is the Communication for Development (C4D) Manager at UNICEF in Afghanistan. Previously, Cássia has worked in the development organisations as Communication Specialist in Portugal, Thailand, Finland, England, Angola and Brazil.

\section{Cicilia M. Krohling Peruzzo}

University of State of Rio de Janeiro (Brazil)

ORCID: 0000-0002-6384-8848

kperuzzo@uol.com.br

PhD in Communication Science from the University of São Paulo, Brazil (ECA-USP). Professor at University of State of Rio de Janeiro. Author of the books "Relações públicas no modo de produção capitalista", "Comunicação nos movimentos populares: a participação na construção na cidadania" and "Televisão comunitária: dimensão pública e participação cidadã na mídia local". She organized some book collections and has articles published in several national and international scientific journals. Member of the Arts and Communication Advisory Committee of CNPq (2016-2019). 